Piotr Goś *, Jarosław Chmielewski **, Marta Janczura *, Damian Gorczyca **, Ewa Żyfka-Zagrodzińska **

\title{
Chemical structure, synthesis, and physical and chemical properties of porous polymers as materials applied in analytical chemistry and environmental protection
}

\section{Budowa, otrzymywanie oraz właściwości fizyko-chemiczne polimerów porowatych jako materiałów do zastosowań w analityce chemicznej i ochronie środowiska}

* Dr inż. Piotr Goś, mgr Marta Janczura - Department of Inorganic and Analytical Chemistry, Faculty of Pharmacy, Medical University of Warsaw, Banacha 1 Street, 02-097 Warsaw, e-mail: gospiotr@o2.pl

\author{
** Dr Jarosław Chmielewski, dr inż. Damian Gorczyca, mgr inż. Ewa Żyfka- \\ Zagrodzińska - Institute of Environmental Protection - National Research \\ Institute, Krucza 5/11D Street, 00-548 Warsaw
}

Keywords: monomers, polymers imprints, metal ions, adsorbents, porous materials

Słowa kluczowe: monomery, polimery imprintowane, jony metali, adsorbenty, materiały porowate

\begin{abstract}
This article is part of a series devoted to discussing strategies for the synthesis of ion-imprinted polymers and molecularly imprinted polymers, their chemical structure and great potential, which may be used in porous material design, analytical chemistry, environmental protection and other areas of science.

The presented work constitutes a basis for a better understanding of what porous polymers are, how we can synthesise them and how to foresee their properties, which can be later used in studies of environmental pollution and analytical chemistry.
\end{abstract}

๑ IOŚ-PIB

\section{INTRODUCTION}

Printing technology and mapping of the molecular ion is a relatively simple and inexpensive method for synthesising porous polymers with specific properties of molecular recognition of a certain compound, its derivatives or a single enantiomer, and an ion in the case of ion imprinted polymer [Yan and Ho Row 2006, Aleksander et al. 2006, Vasapollo et al. 2011]. Even though this technology has been known for over 30 years, only in recent years has it rapidly developed [Karim et al. 2005]. Using the technique of molecular imaging, we obtain a polymer whose properties resemble naturally occurring receptors as well as absorption systems, and can be used in the separation and analysis of biological and environmental samples. Polymers with a trace of molecularly imprinted polymers have the ability to recognise both simple organic molecules as well as structurally complex ones, e.g. amino acids and proteins [Bossi et al. 2007, Scorrano et al. 2011, Morelli et al. 2010]. Conversely, porous polymers with mapped metal ions of IIP selectively recognise and adsorb only certain ions, which has found practical applications, inter alia, the process of removing contaminants [Pichon and Chapuis-Hugon

\section{Streszczenie}

Niniejszy artykuł to jeden z cyklu artykułów poświęconych omówieniu strategii otrzymywania polimerów imprintowanych jonami metali oraz polimerom ze śladem molekularnym, ich budowie oraz ogromnemu potencjałowi, który może zostać wykorzystany przy projektowaniu materiałów porowatych do zastosowań w szeroko pojętej analityce chemicznej, ochronie środowiska jak również innych dziedzinach nauki. Prezentowana praca stanowi bazę dla lepszego zrozumienia, czym są polimery porowate, w jaki sposób je otrzymywać i jak przewidywać ich właściwości, które następnie można wykorzystać do badań zanieczyszczenia środowiska i w szeroko pojętej analityce chemicznej.

2008], the separation of samples [Maliszewska-Mazur 2010, Pichon and Chapuis-Hugon 2008, Tamayo et al. 2007, Andersson 2000, Sellergen 2001, Wel and Mizalkoff 2007, Paluszek 2010], and the determining of heavy metals in food and ground water [Puoci et al. 2007]. Furthermore, porous polymers obtained by means of the imprinting technique are widely used as: drug carriers [Hilt and Byrne 2004], adsorbents for SPE [Bereczki et al. 2001, Hu et al. 2005] and stationary phases in chromatography [Ching-Ching and Wen-Chien 2001, Feng et al. 2006].

There are several methods for synthesising such polymers. The simplest one is a mixture of the model, which may be a molecule or an ion, with a suitably selected functional monomer, a crosslinking monomer and a free radical initiator in a suitable solvent, followed by UV radiation or heating up the polymerisation mixture to induce the polymerisation process. During the polymerisation process, a complex is formed between the template and the functional monomer, which is stabilised by the cross-linking monomer. Then, after the polymerisation process, molecules or ions are removed from the polymer matrix in the extraction 
process, and the resulting polymer has a permanent 'memory', which allows subsequent and selective pattern binding. The formed three-dimensional space is complementary in terms of shape and chemical characteristics relative to the standard. The durability of the binding sites is retained by binding monomers, which, in turn, maintain functional monomers in the optimal configuration to allow the rebinding of a previously deleted molecule or ion [Vasapollo et al. 2011].

\section{MATERIALS AND METHODS}

Using the knowledge of appropriate specific and non-specific interactions between the monomer and reference molecule ion, it is relatively easy to obtain a polymer network of the binding sites. In the literature, there are two common strategies used mainly in the synthesis of the porous polymers, dependent on the interaction between the particle embeddable (standard) and the monomer [Yan and Ho Row 2006]. The first, developed by Wulff and Sarche, is based on covalent bonds, and the other, which calls for noncovalent interactions between the template and the monomer molecule, has been proposed by Arshadya and Mosbach [Bossi et al. 2007]. In both cases, the functional monomers are selected with the aim of allowing an correct interaction with the pattern functional groups. Selective binding sites are formed by covalent bonds or by non-covalent interactions, often between functional groups of the imprinted molecule and monomer.

\subsection{The strategy of creating porous polymers based on covalent bonds}

For the synthesis of polymers with a molecular trace based on covalent bonds, the molecule mapped from the polymerisable functional monomer is linked by a covalent bond. It is a strong bond, and thus there is often a problem with the complete removal of the template molecule from the polymer matrix. As already mentioned, the first of the methods was used by Wulff et all [1973], who synthesised polymers containing particles in a matrix of sugars or amino acid derivatives. The authors showed that in polymers obtained by this technique, specific adsorption selectivity increases with the amount of binding monomer [Yan and Ho Row 2006].

\subsection{The strategy of creating a porous polymer based on non-covalent bonds}

During the synthesis of the polymer granules, which is based on the principle of non-covalent interactions between the particle imprints and the polymer, the specific binding regions are formed spontaneously, which provokes interactions between the particle and the embeddable functional monomer, which has been previously cross-linked. The reference molecule binds to the thus obtained polymer matrix, using ionic bonds, hydrophobic interactions and hydrogen bonds. In most cases, the formation of non-covalent interactions between the model and the monomer is stabilised by hydrophobic conditions, while strongly hydrophilic solvents may weaken such interactions. Also, be aware that some molecules, in particular those containing only one functional group, e.g. an isolated carboxyl group, usually produce polymers with limited molecular properties recognition, which have little practical use. Therefore, it is important to understand the principles of optimisation methods for the synthesis of polymers with a trace of molecular-based non-covalent bonds. An appropriate understanding of them may allow the design of molecularly imprinted polymers having a large number of binding sites with high affinity mapped molecules. Also, the increase in the number of interactions between the pattern and the polymer can lead to better affinity and greater selectivity of the binding site. It should also be noted that in the case of the method of synthesis with a trace element using non-covalent molecular interactions, the number of functional groups in the binding site of the polymer does not result directly from the stoichiometry formed in the pre-polymerisation complex. It is defined and determined during polymerisation. It should also be taken into consideration that great difficulties are still being encountered in characterising the binding sites of structures during and after polymerisation, and these processes still constitute a considerable challenge [Yan and Ho Row 2006].

\subsection{Structure and properties, and the effect of the type and amounts of reactants on the process of preparing porous polymers}

In the polymerisation process between the particle and the pattern of functional monomer, non-covalent bonds or stronger covalent bonds are formed. Their formation is determined by a number of factors which will ultimately determine the quality and durability of the obtained polymer [Luliński et al. 2008]. The most important parameters that influence the molecular printing process are the molar ratio of the binding monomer to the functional monomer, and the ratio of the functional monomer to the amount of a model. Also important are the type and volume of porogen, as well as the type and amount of the used initiator. For the synthesis of polymers with mapped metal ions, one of the most important steps of the polymerisation process is ion complexation by the functional monomer. Creating the organometallic pre-polymerisation complex depends considerably on the concentration of functional monomer, because it directly interacts with the metal ion. When the monomer concentration in the reaction mixture is too high, non-specific adsorption occurs, while in the case of too low a concentration of the monomer, the polymer is formed with a lower amount of functional groups, and therefore with inefficient binding sites and low adsorptive capacity. It should be emphasised that the wrong choice of the molar ratios of the reactants has a huge impact on the morphology and stability of the polymer matrix. When planning the synthesis, it must be taken into account that the concentration of cross-linking monomer needs to be adapted to the concentration of functional monomer. It is also important for the pattern that the functional monomer, crosslinking agent and initiator dissolve in the same solvent. Suitable attention also needs to be paid to the selection of a suitable porogen, as the volume and type of solvent also affects the strength of the interaction between the polymer matrix and a model. In the 
process of preparation of the porous polymers, the free radical polymerisation reaction is used. Free radicals are generated during the thermal or photolytic decomposition of the initiators, most commonly diazo- or peroxide compounds. A very important element of the polymerisation process is the proper selection of the amount of initiator in relation to the other components of the reaction. A too small amount of initiator leads to a reduction in temperature during the polymerisation, which significantly affects the formation of the wrong cavities within the polymer structure. Therefore, it is necessary to provide a minimum amount of initiator able to rip all the double bonds which have functional and cross-linking monomers [Yan and Ho Row 2006].

\subsection{Structure and properties of functional monomers}

The selection of functional monomers in the polymerisation process is one of the most important elements in order to ensure the interaction of complementary molecules with the copied polymer matrix. During the synthesis of the porous polymer, which is based on covalent interactions, the effect of the ratio of a functional monomer to the amount of the model is not important because it is the pattern that decides about the amount of formation and stoichiometry of binding sites. For the synthesis of porous polymers, in which we deal with non-covalent interactions, the optimum ratio of the pattern to the amount of functional monomer is obtained empirically, through the creation of several different polymers with different stoichiometry of the reactants used. Functional monomers are responsible for interaction in the formed binding polymer sites, so it is important to match the functionality of a molecule model to the monomer (e.g. a hydrogen bond donor with a hydrogen bond acceptor). Mostly, in the synthesis of mapped polymers with metal ions, two or more different functional monomers are used (co-polymerisation) [Yan and Ho Row 2006].

\subsubsection{Acid monomers}

The most functional monomers used in the polymerisation process, which is based on non-covalent interactions, are acrylic acid and meth acrylic acid. Carboxyl groups present in both compounds may form hydrogen bonding with a pattern of molecules, as well as influence the dipole-dipole interactions. With such weak interactions, a template molecule may be easily removed from the polymer matrix by washing with aqueous base, acid or methanol. Studies by Piletską et al. [2009] have shown that acidic monomers are more effective in the formation of ionic bonds than basic monomers [Vasapollo et al. 2011]. In addition, ionic interactions may be enhanced by using volatile monomers with stronger acidic properties, such as trifluoromethacrylic acid [Luliński et al. 2008].

\subsubsection{Basic monomers}

In the literature, many compounds employed as monomers having basic properties that were used to obtain porous polymers are described. However, unquestionably the most commonly used in the synthesis is 2-vinylpyridine and 4-vinylpyridine. These compounds may form hydrogen bonds with the hydrogen molecule and acid-base systems. In addition, one should also remember the possibility of $\pi-\pi$ interactions between the molecule and the polymer pattern, which are responsible for the formation of non-specific binding sites in the polymer matrix [Luliński et al. 2008].

\subsubsection{Neutral monomers}

Due to the efficient interaction of the model molecule, neutral monomers are widely used in the synthesis of polymers with a molecular trace. The most widely used application concerns the synthesis of acrylamide and its $\mathrm{N}$-alkyl derivatives [Kapłon 2011].

\subsection{Crosslinking monomers}

Crosslinking monomers, also known as binding monomers or 'cross-linkers', significantly influence the selectivity of the synthesised polymer in relation to the model particle. The appropriate selection of binding monomer is very important to provide complementary interactions between the model and the functional monomer. In a polymer with a molecular trace and a mapped ion, the binding monomer fulfils three main functions. Firstly, the cross-linking monomer is important in controlling the morphology of the polymer matrix, whether it is a gel-type polymer, microporous or powder. Secondly, it provides stabilisation of the formed binding site, and finally it significantly affects the mechanical stability of the formed polymer. In the process of synthesising the porous polymer in free radical polymerisation, it is necessary to add the cross-linking monomer in large excess compared to the other reactants to ensure the optimum porosity and mechanical stability of the formed material. The amount of cross-linking monomer should be adequate in order to ensure the stability of the binding sites. A high degree of cross-linking allows maintaining the three-dimensional structure of the binding site, both in terms of shape and function, whereby the functional groups are maintained in the optimum configuration of the re-binding of the pattern molecule, which allows the receptor to recognise the original pattern. It should be added that there are also cross-linking monomers capable of binding a printed particle and thus they also serve as functional monomers [Yan and Ho Row 2006].

In the synthesis of ion-imprinted polymers and with a molecular trace, the most useful are divinylbenzene (DVB) and ethylene glycol dimethacrylate (EGDMA). As cross-linking monomers, there are the frequently used compounds, which have in their structure more than one acrylate group, e.g. trimethylolpropane trimethacrylate (TRIM), pentaerythritol triacrylate (PETRA) and pentaerythritol tetrakrylan (PETE). These compounds have even better properties when compared to EGDMA, while the alternative to EGDMA is 1,3-diizopropylenobenzen. The literature also mentions the use of other monomers, i.e. 1,4-butanediol dimethacrylate and triethylene glycol dimethacrylate [Vasapollo et al. 2011].

\subsection{Initiators for the process of polymerisation}

Free radical polymerisation initiators used in the process of preparing polymers with a molecular trace and metal ions 
imprinted polymers are usually diazo- and peroxide compounds. The polymerisation initiators demonstrate stability at room temperature, and during polymerisation, when the temperature ranges from $60^{\circ} \mathrm{C}$ to $150^{\circ} \mathrm{C}$, they degrade at a pre-determined rate to produce free radicals, thereby initiating the polymerisation reaction [Kapłon 2011]. These compounds are used in a small amount compared to the amount of monomer used. Most added $1 \mathrm{wt} \%$ or $1 \mathrm{~mole} \%$ based on the total content of mol of polymerisable double bonds. The degree and rate of initiator decomposition may be controlled in many ways, by high temperature, the intensity of UV radiation and by the use of chemical or electrochemical means, depending on the chemical nature of the initiator [Yan and Ho Row 2006]. In the case of the polymers MIP and IIP, the most commonly used are azobisisobutyronitrile (AIBN), azobis(1cykloheksanonitryl) and 4,4'-azobis(4-cyanovaleric acid). These compounds belong to the group of azo compounds, which are derivatives of methyl diazen $(\mathrm{HN}=\mathrm{NH})$.

\subsection{Technology of receiving the porous polymer- polymerisation block}

The polymerisation in the block is one of the most common methods of synthesis of the porous MIP and IIP. During the synthesis, the polymerisation mixture is formed, which comprises a pattern, a functional monomer, a cross-linking agent and an initiator. Next, it is hung in a properly selected porogen and polymerised. The resulting polymer block is ground to particles sized 20-100 $\mu \mathrm{m}$, which are then sieved. The polymerisation process usually takes from 2 to 6 hours.

Although the block polymerisation is easy to conduct and does not require the use of modern equipment, it has some drawbacks. First, the obtained polymer particles have non-uniform size and shape. The homogenisation process usually takes quite a long time and can cause damage to the structure of the binding sites, thereby reducing the adsorptive capacity of the polymer. This type of synthesis is primarily useful in industrial processes that yield large quantities of the polymer [Modise 2010]. Metilda et al. [2007] applied polymerisation in the block to synthesise uranium-mapped polymer in order to monitor the compactness of this toxic element in the environmental samples. The received polymer showed good selectivity with respect to uranium, even in the presence of large amounts of other heavy metal cations [Metilda et al. 2007].

\subsection{Application of polymers}

The synthesis of polymer by weight was applied to prepare the polymer, which was used as the adsorbent solid phase extraction

\section{REFERENCES}

ALEKSANDER C., ANDERSSON H. S, ANDERSSON L. I., ANSELL R. J. 2006. Molecular imprinting science and technology: a subway of the literature for the years up to and including. J. Mol. Recognit., 19:106-180. for $\mathrm{Cu}, \mathrm{Ni}, \mathrm{Pb}$ and $\mathrm{Zn}$ from sea water. The resulting polymer was characterised by good properties and showed a recovery of $99 \%$ for $\mathrm{Cu}, \mathrm{Ni}, \mathrm{Zn}, \mathrm{Pb}$ and for $\mathrm{As}$ and $\mathrm{Cd}$ at $70 \%$ [Otero-Romani et al. 2009].

Beltran et al. [2009] used polymerisation mass to obtain a polymer for the selective extraction of carbamazepine and oxcarbazepine from a urine sample. As a part of the calibration of carbamazepine, methacrylic acid (MAA) was used as the functional monomer, and 80-divinylbenzene (DVB-80) and 80-divinylbenzene mixture (DVB-80) with ethylene glycol dimethacrylate (EGDMA) as crosslinking monomers. The resulting polymer was characterised by good adsorption properties and showed $90 \%$ recovery for carbamazepine and $83 \%$ for oxcarbazepine [Beltran et al. 2009]. Suspension polymerisation is another technique used to produce polymers with a molecular trace and mapped metal ions. Synthesis of polymers by this method is fairly simple and does not require mechanical milling of the prepared material. If a solution where the synthesis is conducted is sufficiently diluted, it allows us to obtain homogeneous material comprising particles having a spherical shape. During the synthesis, the mixture of a functional monomer, a binding monomer, a pattern and a porogen is added to a solution forming the dispersed phase in order to form an emulsion. The dispersing solvent may be an aqueous or organic solution of fluorocarbon. It should be remembered that water can have a negative impact on the formation of non-covalent bonds between the molecule and the functional monomer. Using this method, we can shorten the polymerisation time to less than 2 hours.

The amounts of added monomer (bonding and functional) and of the pattern are larger in comparison to other methods to compensate for the loss of these particles in the dispersed phase, which does not participate directly in the polymerisation process. This means that the initiator must be dissolved in the phase containing the monomers and not dissolved in the dispersed phase. This method allows the obtaining of particles having a diameter between 5 and $50 \mu \mathrm{m}$. The main disadvantage of this process is the use of special fluorinated surfactants, which are quite expensive but can be recovered after the synthesis [Modise 2010].

\section{CONCLUSSIONS}

Porous polymers with a molecular trace and mapped metal ions have good chemical and thermal stability, as well as resistance to 'aggressive' solvents. The advantage of these polymers is their low cost and easy synthesis, storage stability, repeatability of the operation, repeated adsorption and desorption, mechanical strength and resistance to high temperature and pressure.

ANDERSSON L. I. 2000. Moleculary imprinting: development and applications in the analytica chemistry field. J. of Chromatogr. B, 745: 3-13. 
BELTRAN A., MARCE R. M., CORMACK P. A. G., BORRULL F. 2009. Synthesis by precipitation polymerisation of moleculary imprinted polymer microspheres for the selective extraction of cabamazepine and oxacarbamazepine from human urine. J. of Chromatogr. A 1216: 2248-2253.

BERECZKI A., TOLOKAN A., HORVANI G. 2001. Determination of phenytoin in plasma by moleculary imprinted solid- phase extraction. J. of Chromatogr. A, 930:31-38.

BOSSI A., BONINI F., TURNER A.P.F. 2007. Moleculary imprinted polymers for the recognition of proteins: The state of the art, Biosensors and Bioelectronics. 22: 1131-1137.

CHING-CHING H., WEN-CHIEN L. 2001. Chromatographic resolution of the enantiomers of phenylpropanolamine by using moleculary imprinted polymers as the stationary phase. J. of Chromatogr. B, 765: 45-53.

FENG L., XIAO L., SIU- CHOON N. 2006. Enantioselective molecular imprinting polymer coated QCM for the recognition of L-tryptophan, Sensors and Actuators B. 113: 234-240.

HILT Z. J., BYRNE E. M. 2004. Configuration biomimiesis in drug delivery molecular imprinting of biologically significant molecules. Advanced Drug Delivery Reviews. 56: 15991620.

HU S. G., LI L., HE X. W. 2005. Comparison of trimetoprim moleculary imprinted polymers in bulk and in sphere as the sorbent for solid- phase extraction and extraction trimethoprim from human urine and pharmaceutical tablet and her determination by high- performance liquid chromatography. Anal. Chim. Acta, 537: 215-222.

KAPŁONŁ., Polimeyzacja w masie styrenu i jego pochodnych jako materiału do konstrukcji scyntylatorów. 2011. Wydawnictwo Uniwersytet Jagielloński.

KARIM K., BRETON F., ROUILLON R. 2005. How to find effective functional monomers for effective moleculary imprinted polymers? Advanced Drug Delivery Reviews. 2005, 57: 17951808.

LULIŃSKI P., CIEŚLAK A., MACIEJEWSKA D. 2008. Synteza polimerów imprintwanych dopaminą i teoretyczna analiza oddziaływań międzycząsteczkowych w kompleksie prepolimeryzacyjnym, Biul. Wydz. Farm. WUM. 1: 1-11.

MALISZEWSKA-MAZUR M. 2010. Reach - ecological criteria and procedures for evaluation of chemicals. Environmental Protection and Natural Resources. 42: 11-23.

METILDA P., PRASAD K., KALA R. 2007. Ion imprinted polymer based sensor for monitoring toxic uranium in environment al samples. Anal. Chim. Acta, 582: 147-153.
MODISE R.2010. An lon imprinted polymer for the determination of $\mathrm{Ni}(\mathrm{II})$ ions from mine tailing samples. Rhodes University.

MORELLI I., CHIONO V., VOZZI G. 2010. Moleculary imprinted submicrospheres for applications in a novel model biosensorsfilm. Sensors and Actuators B: Chemical, 150: 394-401.

OTERO-ROMANI J., MOREDA-PINEIRO A., BERMEJOBERRERAP.2009. Inductivelycoupled plasma-opticalemission spectrometry/mass spectrometry for the determination of $\mathrm{Cu}$, $\mathrm{Ni}, \mathrm{Pb}, \mathrm{Zn}$ in seawater after ionic imprinted polymer based solid phase extraction. Talanta. 79: 723-729.

PALUSZEK J. 2010. Effect of addition of agroaquagel 420 on physical properties of eroded luvisol. Environmental Protection and Natural Resources. 44: 107-116.

PICHON V., CHAPUIS-HUGON F. 2008. Role of moleculary imprinted polymers for selective determination of environment al pollutants. A Reviu. Anal. Chim. Acta, 622: 48-61.

PILETSKA E., GUERREIRO A., WHITCOMBE M., PILETSKY S. 2009. Influence of the polymerization conditions on the performance of molecularly imprinted polymers. Macromolecules, 42: 4921-4928.

PUOCI F., CIRILLO G., CURCIO M. 2007. Moleculary imprinted sold phase extraction for selective HPLC determination of a-tocopherol in by leaves. Anal. Chim. Acta. 593: 164-170.

SCORRANO S., MERGOLA L., DEL SOLE R. 2011. Synthesis of Moleculary Imprinted polymers of Amino Acid Derivates by Using Different Functional Monomers. Int. J. Mol. Sci 12: 1735-1743.

SELLERGEN B. 2001. Imprinted chiral stationary phases in highperformance liquid chromatography. J. Chromatogr. A, 906: 227-252.

TAMAYO F. G., TURIEL E., MARTIN-ESTEBAN A. 2007. Moleculary imprinted polymers for solid-phase extraction and solid phase microextraction: Recent developments and future trends. J. of Chromatory. A, 1152:32 - 40.

VASAPOLLO G., DEL SOLE R., MERGOLA L. 2011. Moleculary Imprinted Polymers: Presents and Future Prospective. Int. J. Mol. Sci., 12: 5908-5945.

WEL. S., MIZALKOFF B. 2007. Recent advances on noncovalent molecular imprints for affinity separations. J. Sep. Sci, 30:1794-1805.

WULFF G., SARHAN A., ZABROCKI K. 1973. Enzyme-analogue built polymers and their use for the resolution of racemates. Tetrahedron Letters 14, 44: 4329-4332.

YAN H., HO ROW K. 2006. Characteristic and Synthetic Approach of Moleculary Imprinted Polymer. Int. J. Mol. Sci. 7: 155-178. 